\title{
實驗的貧血二於ケル聽器障碍二就テ
}

\author{
第六編「サポニン」貧血ニ於ヶル聽器障碍二就テ
}

Dr. Ituo Iwata : Über die Störungen des Gehörorgans bei der Anämie.

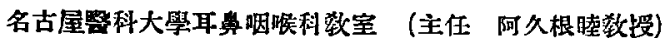

學士 岩思溾采

\section{內 容目次}

\section{第一占 序䓂 \\ 第二章 筫驗材料及ビ方法 \\ 第三章 實驗成綪}

第一節 全身狀剪

第二節 血液所見

第三節 プタイエル氏昨

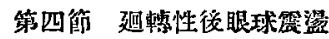

第五節 丙荿/肉眼的所是

第六節 㯖哭，苪理組紻學的所見

第四章 蟌括泣二考穼

第五章 結 論

\section{第 一 章}

序

Saponin 八庫ク植物界二存在シ重要ナル作用 ヨ有スル物質ナルモ，基本植物，異ルニッレテ 分子構造或ハ性啠二モ差異厂リ。

「サボンン」ハ化學的二八糖原體二屬シ．化學操 作ニョリテ其理學的性啠 7 變ズレ共常 $=「 ヒ ョ$ レステリン」トノ特異漞和力二因儿共通ナル毒 性 7 有シ. 其最モ强キハS Sapotoxin $\left(\mathrm{C}_{17} \mathrm{H}_{30} \mathrm{O}_{10}\right)$ $+y$

「サボニン」八細胞毒トシテ局所ニ於テハ㘳ク敌 物，皮局或八粘膜》侵シ發赤. 燒灼. 疼痛. 炎 定. 分泌元進习惹起七シメ. 内服シテ八健全ナ ル周腸ヨリ四收サル、事ナキモ。吐演习起シ延
言

イテハ胃腸＼cjkstart炎症习起シ。皮下=注射スレバ激

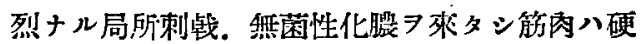
直シ興鹪性ア失七。臓器二於テハ細胞ト結合シ 其機能习失ハシムルニ至ル。最モ特異ナルハ血 液二對スル作用 ニシテ游離赤血球ニ於ケルモ， ト生膀ニ於ケルモノト自ラ機轉相等シカラ ズ。而シテ溶血現象八Kobert $=\Xi$ レ゙赤血球 被膜，基質成分タル「ヒョレステリン」ト「サ ボニン」トノ結合ニヨルモノンシテ. 凝集反隹 「メトへモグロビン」形成ヨ起サズシテ溶血スト 1ว.

生體冈 二於テ溶血現象 
毒物 习直接血管内 =注射七ザルベカラス。然レ 共「サポニン」ノ塎血現象二於テハ生體內 =テ

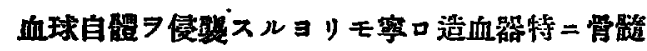
フ侵シ以テ資血フ來タサシメ得ルモノナリ。

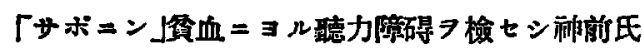

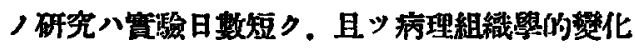
究×X。

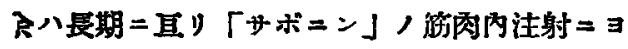

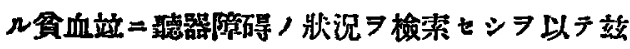
ニ報告セントス。

$$
\text { 第 }=\mathbf{I}
$$

\section{實喻材料及ビ方法}

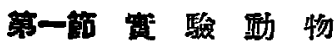

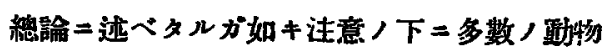

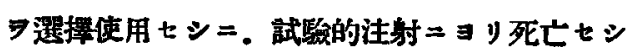
モノ多ク. $300 \mathrm{~g}$ 代ノモノ5頭. $400 \mathrm{~g}$ 代ノモノ 2 頚. 合計 7 頭 7 稍 モ. 倘办不幸中途ニテ死亡七シモノフリテ. 生 鳢固定 $テ$ ナ得タルハ300 g 代,モノ 3 頭. 400 $\mathrm{g}$ 代ノモノ1 頭. 計 4 頭ナリ。

\section{䒜二范 寞 驗 方 法}

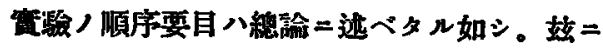
八盗血發生 /方法及ビ其他特殊ナル事項 テ述ベン。

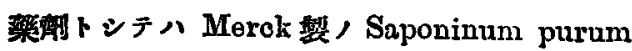
album, $0.2 \%$ 生理的食盟水溶液 7 海日或八陑 日=1 回腹部筋肉内 =注射七り。大腿部八注射 ニ八都合好キモ. 注射部位硬直シ回习重ヌルニ ッレ通動不活沿。步行不能二陷り，全身狀態， 惡化 來タシ易キニヨリ。注意シテ股筋内二注 射スルラ常トセリ。

注射量八最初體重 $1 \mathrm{~kg}=ツ * 1 \mathrm{cac}(0.002 \mathrm{~g})$ ト

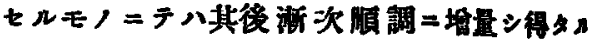
モ. $1.3-1.5 \mathrm{ca} ヨ$ ヨ始メタルモノニテ川全身状

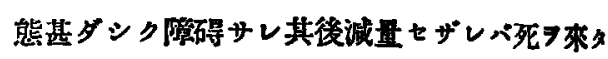

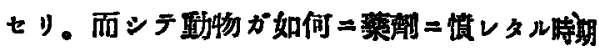
ト踓モ體重 $1 \mathrm{~kg}=ツ+1.6-1.9 \mathrm{ca}$ 以上=八㙁量

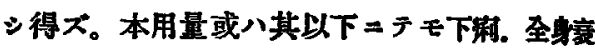
弱甚ダシク致死习招り場合フリ。

故二高度ナル盆血习被生セシメントスルモ。路 り多量ノ注射八行ヒ得ザリキ。血液榆查八1通 1 回トシ. 其間八皆同一量 7 注射スルラ常トを

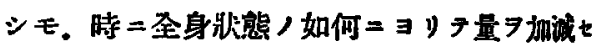
リ.

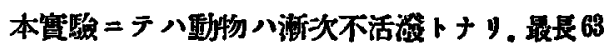
日ニシテ生體固定ア行つノ止ムナキニ至レリ。 固定法. 標本作製ノ箸操作八總諭=述べタルガ 如シ.

\section{策三草}

\section{声 验 成 綪}

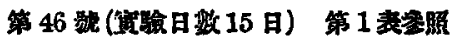

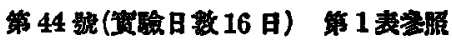

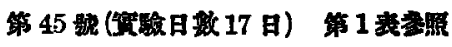

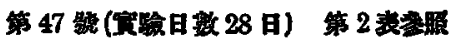

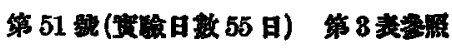

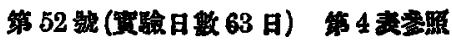

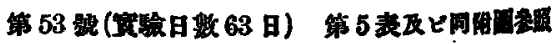

\section{第一箅 圣 身 狀 態}

「サボニン」八强キ局所作用及ど遠撻作用 リ。皮下或八筋肉内二注射七几時八将痛甚多》

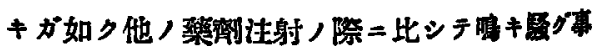
䊅シ。最初用量八艋重 $1 \mathrm{~kg}=シ * 0.002 \mathrm{~g}$ 上

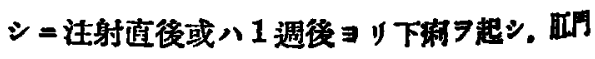
八膨隆シ。渐次元氣消失，運怔不活濩トナッ。 食㗹ハ初メ良好ナルモ次第二不层トナリ。物 
甚ダシク益々衰弱ス。注射部位八觔肉硬遖シ。 時二化㭽 7 來タス事厂リ。洼射量 $0.003 \mathrm{~g}=$ 及

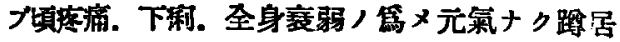

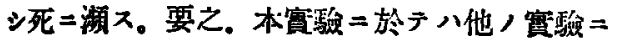
比シテ全身狀態ノ侵サル、事最モ强度ナリ。 體重 消長二就キテハ. 第 44.45.46。47號

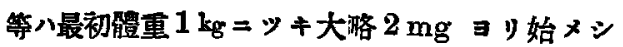
=. 1 週後=5-25g 減少. 次 1 デ泚減シ最後 $(2-4$ 週後) $=30-55 \mathrm{~g}$ 人減少 7 示七リ。

最初 2.3-2.8mg $\exists$ リ始メ隔日二注射习行七比 較的長期邵千約 2 ケ月實驗习繼皎シ得々几第 51.52.53 號等八 1-3 週後=約 $50 \mathrm{~g}$ 娍少シ タルモ．其挠渐次元氣トナリ．固定直前二八略 略宣驗前ノ體重二近キカ或八稍 シテ下溂ノ甚ダシキ時. 全身狀態ノ不良ナル時 八體重ノ減少大ナり。

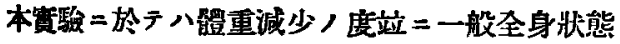

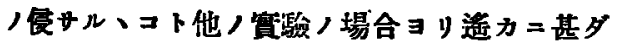
シ.

第二䈗 血 液 所 見

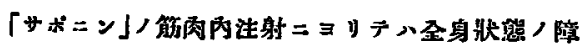
棈高店ニシテ多量/注射キナスナ得ズ。從シテ高度 ナル骨血キ發生シ得ザりキ。䛨勫入表二示をルガ如

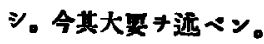

\begin{tabular}{|c|c|c|}
\hline 堛物番㴲 & 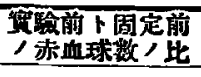 & 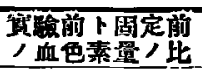 \\
\hline 46站 & $64 \%$ & $71 \%$ \\
\hline 44裙 & $79 \%$ & $93 \%$ \\
\hline 45视 & $83 \%$ & $73 \%$ \\
\hline 47强 & $98 \%$ & $95 \%$ \\
\hline 51號 & $100 \%$ & $89 \%$ \\
\hline 52踢 & $114 \%$ & $103 \%$ \\
\hline 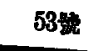 & $102 \%$ & $87 \%$ \\
\hline
\end{tabular}

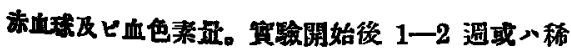

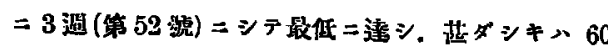

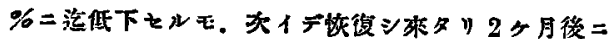
八正常二近キ值キ而入事多り。最後，检血，祭最五 演度ナル筫血二於テモ赤血球数入正常ニシテ血色素 贵 $\leq 87 \%$ (第 53 號). $89 \%$ (第 51 號) *示シ. 此

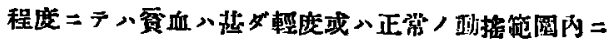
アリト言ノキ得ベシ。

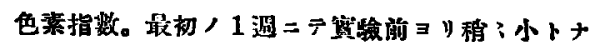

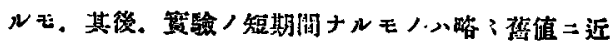

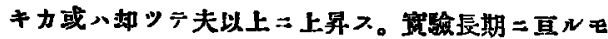
ノ八或ハ大トナり或ハ小トナリ不定ナルそ最後こへ 㮩べテ最初ョリ小トナンり。

異常赫血球。有核赤血球八通管出现をブ。唯第 52

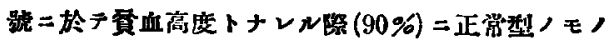
＼cjkstart㒖少ニ認メタルノミナり。

基性斑點そ一般二出現スルコト少ク．第 51. 52

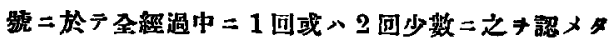
Nノシ 。

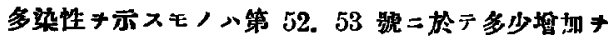

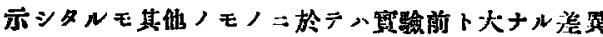
ナシ。

略形赤血球及ビ赤血球大小不同八笛 $\mathbf{4 6}$ 及ビ 45 號， 他八殆ンド常二多少トモ出現セり。

白血球数。第 51 㴲斗除キテ八第 1 回榆掹時 $\Xi . y$ 既二可成り高度八白血球船多キ示スキ常トシ，其後 多少娍少シ動控キ示スモ日数キ重メルニッレ高度ナ

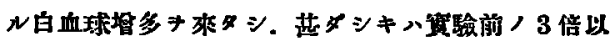
上二達をシュノフリ(第 52 號)。筑 51 號ノ如》日血

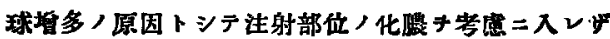

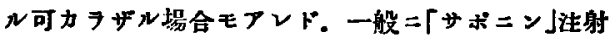

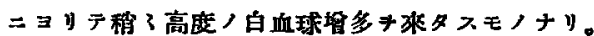
而シテ白血球数卜資血卜ハ平行スルモノニ八非ザル ガ如シ。

白血球ノ分類。留基啫好細胞：殆ンド變化ナシ。

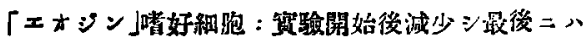

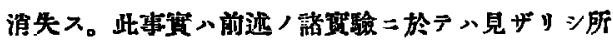
$+y$ 。

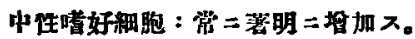

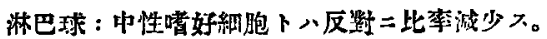

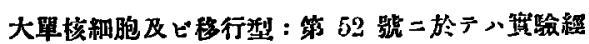

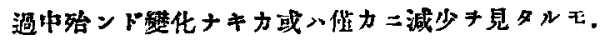

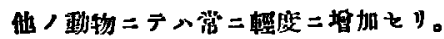




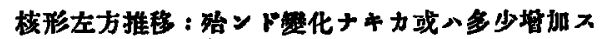
N事フリ。但シ主トシテ捍状校白血球ニシテ. 糐二 奻若型或八骨链細胞キ見Nノミナリ。

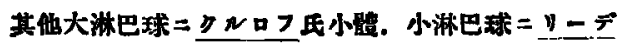

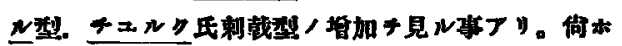

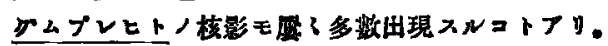

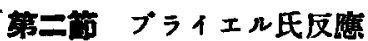

拍手ニ龂シテハ總べテ最後迄反應陽性ナリ。

笛算ニテハ反應一時稍ミ低減スルモ「サポニン」

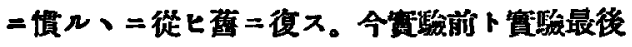
ノ聽カノ比 $\exists$ 示スニ次ノ如シ。

\begin{tabular}{|c|c|c|}
\hline \multirow{2}{*}{ 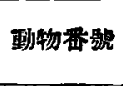 } & \multicolumn{2}{|c|}{ 砧力，比 } \\
\hline & 左. 耳 & 右 \\
\hline 46 躈 & $120 \%$ & $57 \%$ \\
\hline 44 & $67 \%$ & $100 \%$ \\
\hline 45 喝 & $100 \%$ & $100 \%$ \\
\hline 47 繁 & $114 \%$ & $100 \%$ \\
\hline 51 影 & $100 \%$ & $100 \%$ \\
\hline 52 㩆 & $100 \%$ & $120 \%$ \\
\hline 58 㩆 & $117 \%$ & $100 \%$ \\
\hline
\end{tabular}

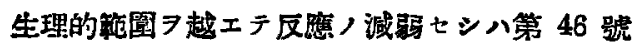
ノ右耳ノ $\bar{\imath}=$ シテ一般=褯力ノ低下八無キモ， ナリ。勇血トノ關係八確認スルシ得ザリシモ。 頜血及ヒ全身狀態ノ恢復 リ。(生理的動墇範園内＝於テナリ．)

\section{第四曾 趈轉性後眠球震海}

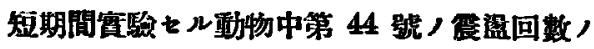
影播 $(70 \%)$ 八正常 7 越ユルモノト云フペク. 其他二於ケル減少八略 こ正常ノ域 7 脆セズ。

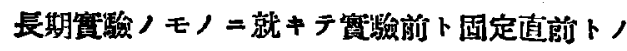

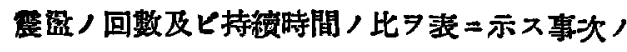
如シ。

第 47 及ど 52 號二於テ八減少セりト看做シ得べ

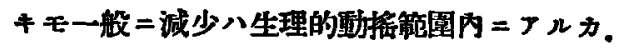

\begin{tabular}{|c|c|c|c|c|}
\hline \multirow{2}{*}{ 理物番禠 } & \multicolumn{2}{|c|}{ 层数 } & \multicolumn{2}{|c|}{ 持㜔時間 } \\
\hline & 右 至 & 右 遇 & 左 至 & 右 \\
\hline 47 跟 & $51 \%$ & $37 \%$ & $86 \%$ & $67 \%$ \\
\hline 51 㩆 & $65 \%$ & $56 \%$ & $78 \%$ & $79 \%$ \\
\hline 52號 & $44 \%$ & $37 \%$ & $60 \%$ & $60 \%$ \\
\hline 53唬 & $74 \%$ & $54 \%$ & $106 \%$ & $74 \%$ \\
\hline
\end{tabular}

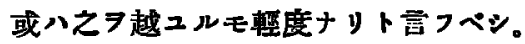

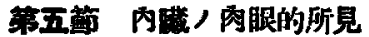

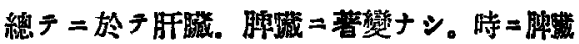
ノ稍に萎縮セルモノフリ。

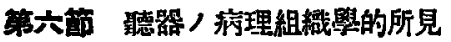

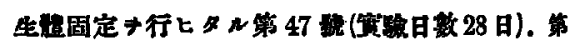

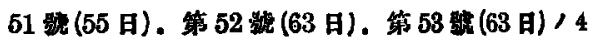
頭こ就キデ退ベン。

\section{第 47 號動物}

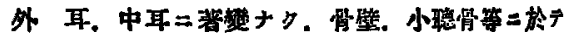

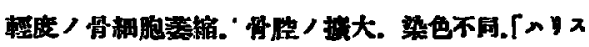
テレーゼ」見ル。

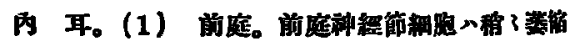
そNモノフルモー般二正常ナり。

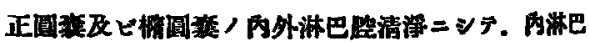

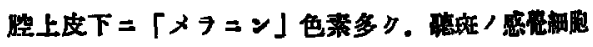

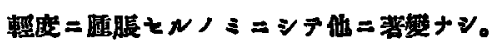

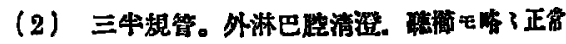
$+1$

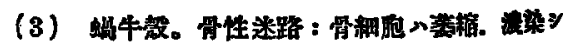

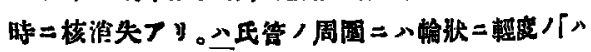

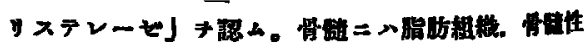

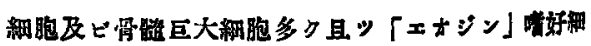
垉甚如多シ。

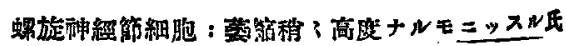
小能的、正常ナり。

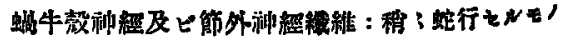
$>$ \%.

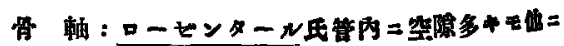
颌督ナシ。

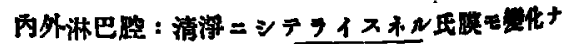




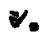

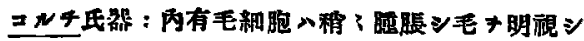

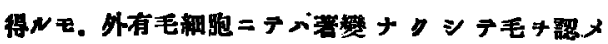
ズ、ヘンを゙ン氏細胞. クタウジサス氏細胞八稍、随

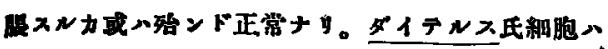

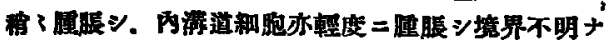

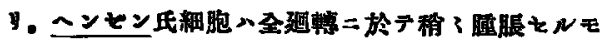

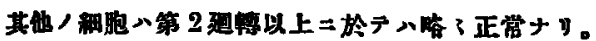

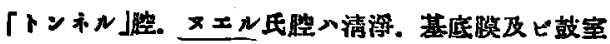

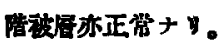

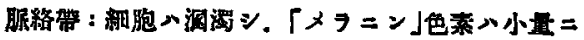

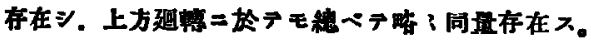

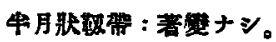

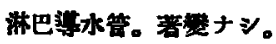

第 51 號動物

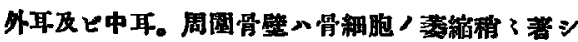

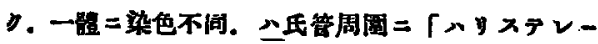

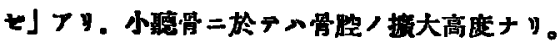

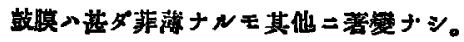

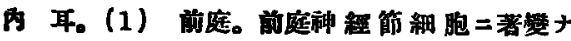

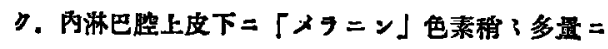

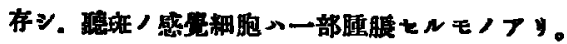

（2）三牛规管、内淋巴腃上皮下二色瑟多量二存

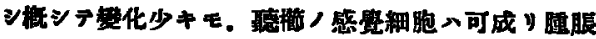
セNモノ多シ。

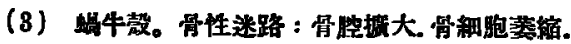

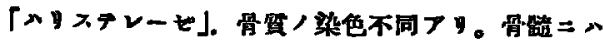

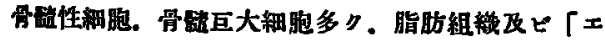
ナジン」嘈好种胞二そシ。

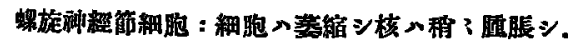
シッスホ氏小㩆稍了粗大ナルガ如シ。

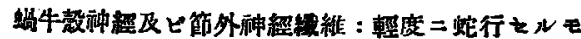
ノ. 又堙䏣をルモノフリ。

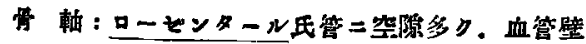
輤了军シ。

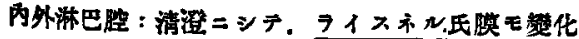
$+*$ 。

ロルチ氐器：內外有毛細胞入略、正常ニシテ毛キ

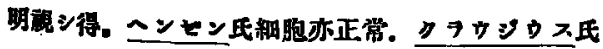

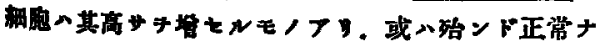

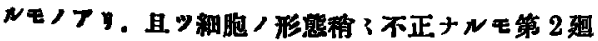

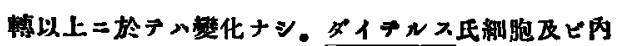

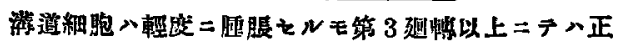

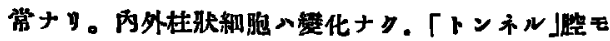

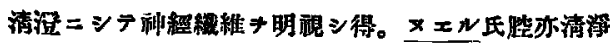
ナ.

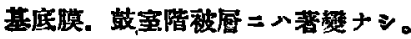

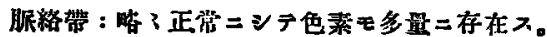

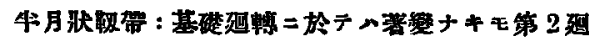
寢ニテネ䄉維ノ排列不正ニシテ空陧キ生シタル所フ ข.

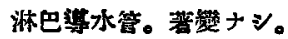

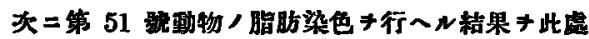
ニ一括シテ远ブレパ: 外耳.中耳ニ於テン顿骨細胞

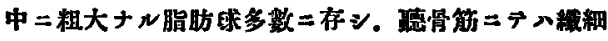

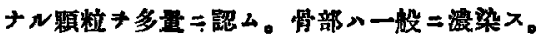

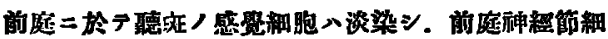
胞及七゙种緸倳維 染入。

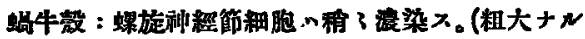
乘䊉少数 $=>$ 》)。

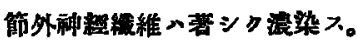
91スネ儿氏膜分淡染ス。

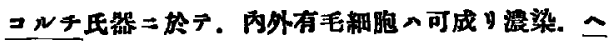

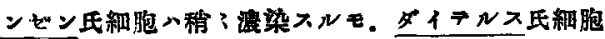

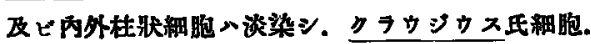

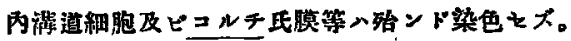

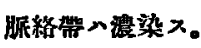

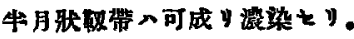

第 52 號㙑物

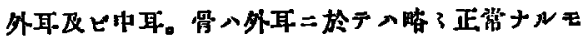

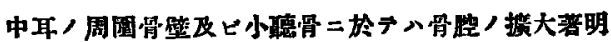

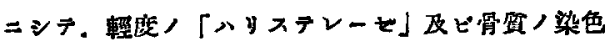
不同フリ。

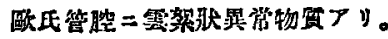

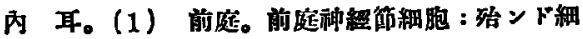

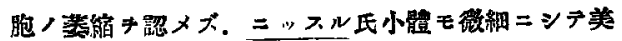
蹬ナル儌キ是ス。

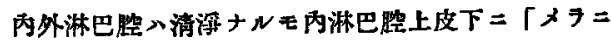
ン」色素存在セで。

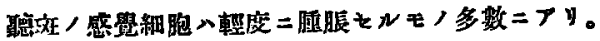

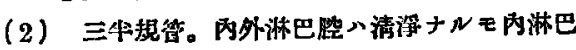


腔上皮下゙二色萫キ蚗ク。

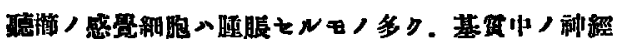

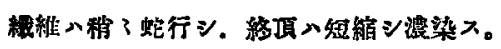

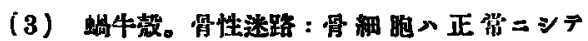

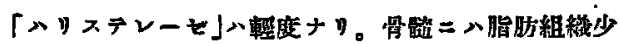

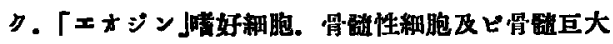
稩胞多シ。

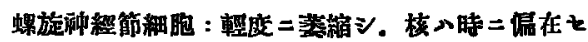

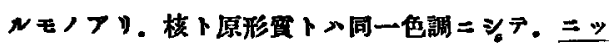

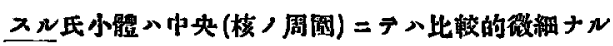
モ周㟫二至レベ粗大トナル。之等笛細胞ノ變化ハ上

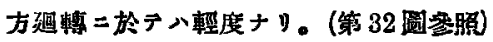

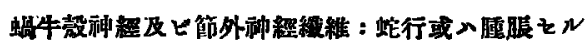
玉人多シ。

骨 軸：ローゼンタール氏管丙八節静胞，周图二

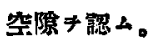

內外淋巴管：清淨ニシテ． + .

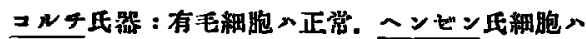

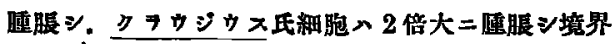

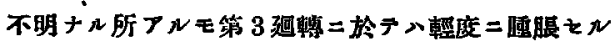

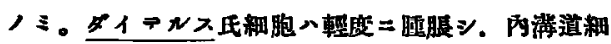

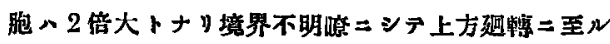

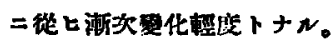

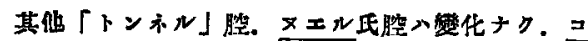
失氏膜. 基底膜. 鼓室階被磨心喀了正常ナy。(第 33 㘣悉炤)

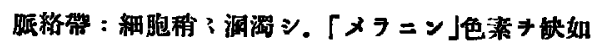
>。

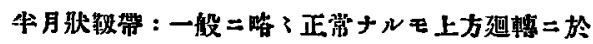
テへ走行不规則ニシテ些陣キ見ル所フ。

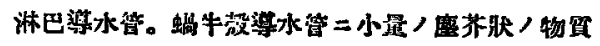
キ証么。

第 53 號 耐 物

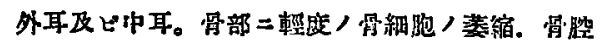
ノ振大キ認么。

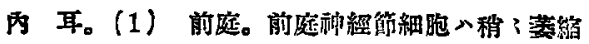
セNモ三ッスN像》正常ナり。

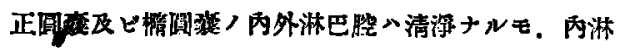
巴践上皮下ニッ「メラニン」色素キ見ズ。

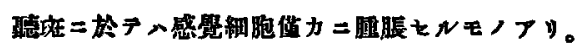

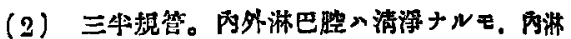

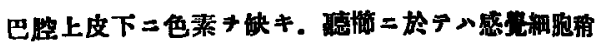

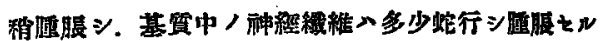
モノキ見Nコトアッ。

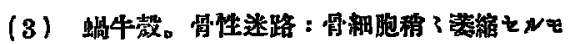

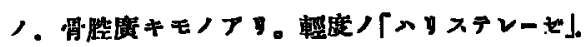

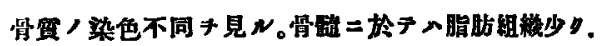

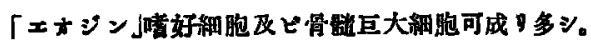

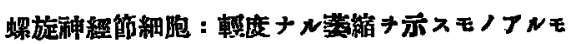

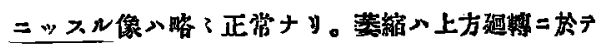
稍了高度ナ、。

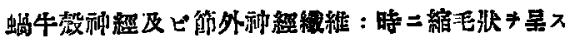

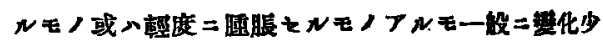
シ。

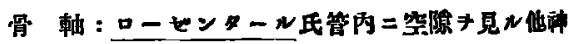

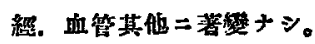

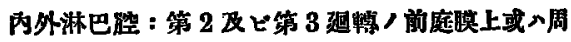

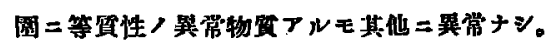

フイスネル氏膜へ㛭變ナシ。

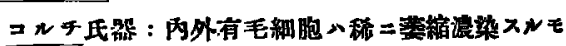

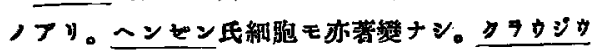

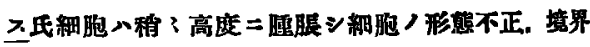

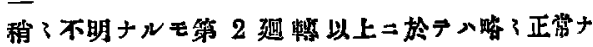

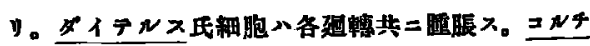

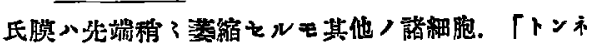

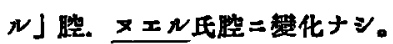

基底膜入稍了厚》第 2 迴轉以上 $=$ 於テ喆室階被層、

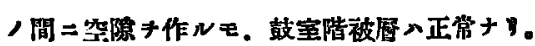

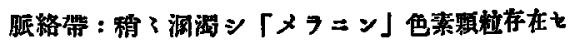
ズ。

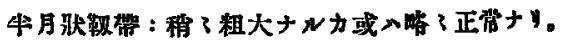

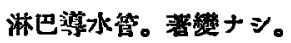

$$
\text { 本䇛，總括 }
$$

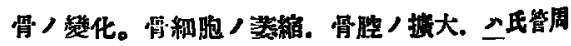

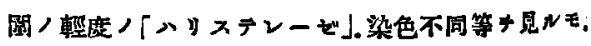
第 51 號二於テッ「メリステレーセ」䅌了高度ナり。

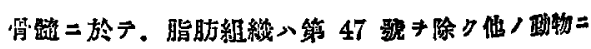

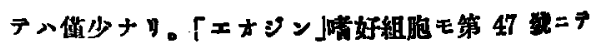

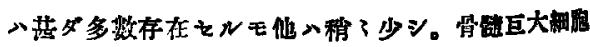
八一般二可成》多シ。

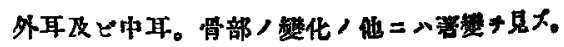




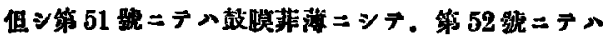

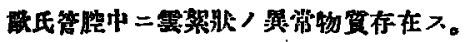

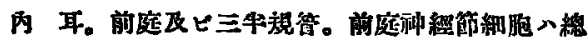

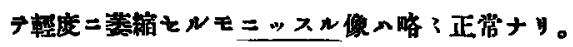

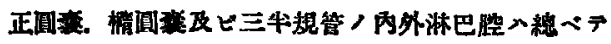
清治ナり。內淋巴整上皮下ノ「メランン」色素八正

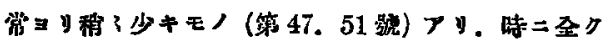
滑失そNモノフリ。(第 52.53 影)

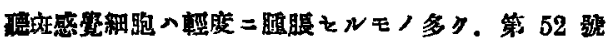
ノミカ其废稍く大ナり。

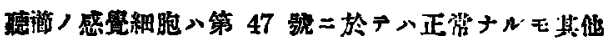
ノ動物二於テ ハ軑度二腄脹入。

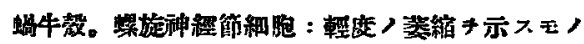

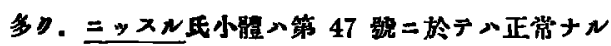

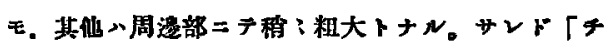

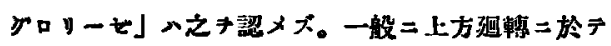

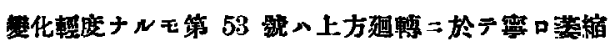
高度ナリ。

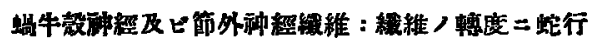
そルモノ(第 47 號)或》更二埂脹そルモノフタ。(第 51. 52. 53 鯄)

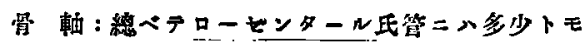

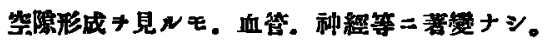

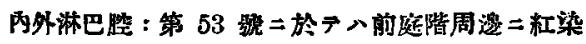

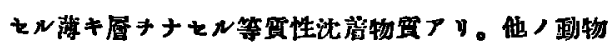

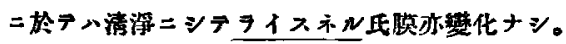

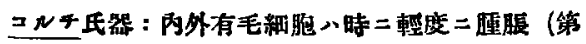

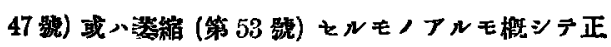
营ナルモノ多シ。

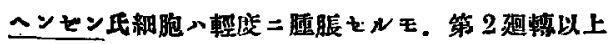

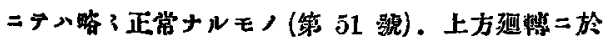

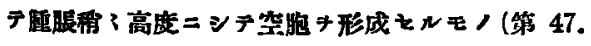

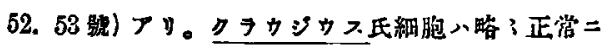

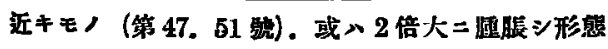
及ビ排列不正ナルモ（第 52. 53 號)フリ。第 52 號

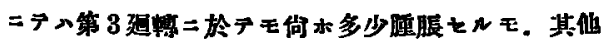

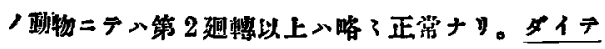

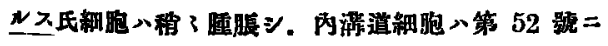

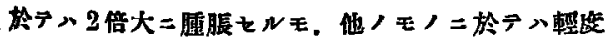

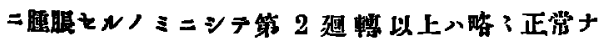

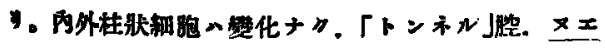

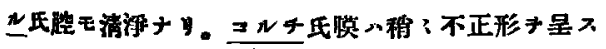

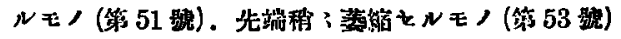
等厂。

基底脱 第 52. 53 暍ニテ八稍了厚ジ。鼓宔階被屏 二䌘化ナシ。

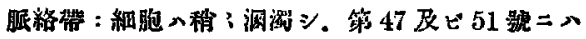

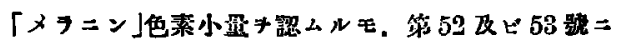
於テハ全ク之キ缺如ス。

牛月狀软帶 : 略、正常ナルモ. 排列稍: 粗ニジ

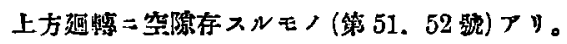

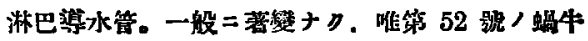

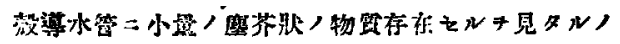
ミナ。

\section{第 四 草}

總括並二考条

「サボニン」注射ニヨリテハ全身狀態ノ侵サル ル事甚ダ大ナルン㣘ラズ筫血八甚ダ相度二シ テ.辞器，變化办極メテ輕シ。

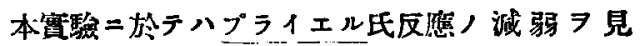
$\boldsymbol{x}_{0}$

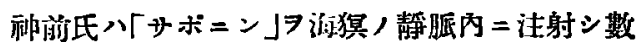

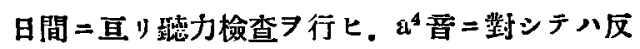
萑減弱シ第3 日或ハ第 5 日二八全ク消失シ数日 ニシテ死亡セりト。乐八筋肉內注射 7 行ヒ且ッ

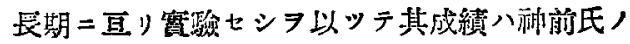

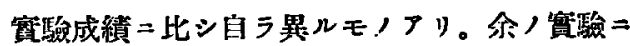
於テ八筫血，登生卜同時二本反隹稍 6 娍弱セル

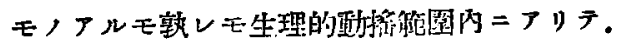
疆力ノ低下ナシト春做シ得べシ。

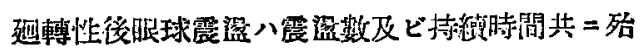

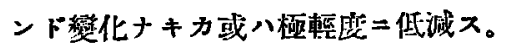

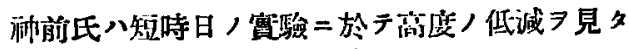

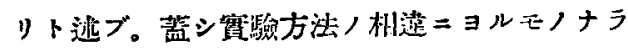

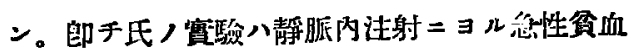

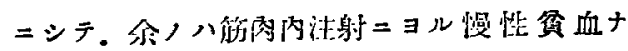


y.

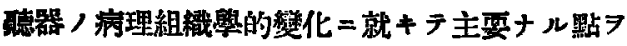
翼グレバ，骨二於ケル軗虔，萎縮退行性變化。

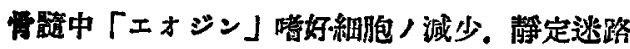

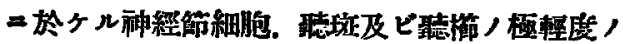

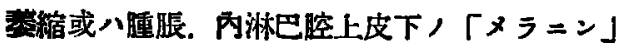

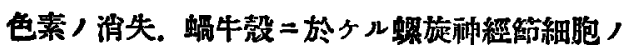

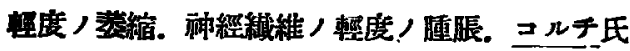

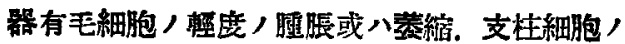
軽度/尰脹. 胍絡帶ノ「メランン」色素/減少 或八消失等ナり。

功物ニヨリテハ以上ノ諸變化ノ認メラレザルモ ノモアリ。

又時二淋巴腔，浔淨习缺クモノナルモ炎症性， 隼化 $\boldsymbol{\text { 認 } メ ス 。 ~}$

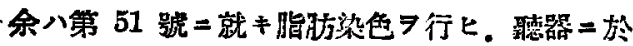

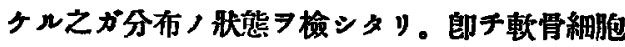
ニテハ粗大ナ几顆粒多ク、聽骨䈃ニテハ微細ナ ルモノワ見. 骨八稍 8 高度二染色シ。前庭䅂末

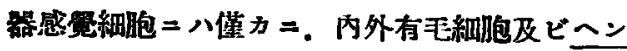
ビン氏細胞=ハ多量二脂肪存在ス。名1モルス 氏細胞。內柱狀細胞．三1 ス六几氏膜等八淡染

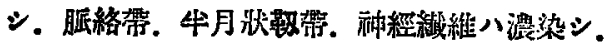
中村氏，正常成熟源猽二於々几所見ト相似， y.

而シテ貧血ノ程度卜聽器二於ケル諸變化トノ間 ニ八明カナル因果關保习認メ難シ。

次ニプライェル氏反應卜螎牛款迷路卜，關係= 就キテハ. プライエル氏反應正常ナルモ。蝪牛 教ニ八転度ノ退行性變化 默關シテハ恰モ教照實驗ニ於ケル病理組樴學 的所見ノ如ク．標本作整二至ル中途二於ケル人 工的變化卜看做ス 7 安虽ナリト信ス。

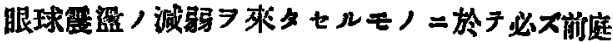

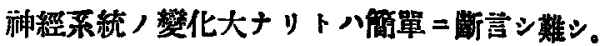
次ニ「メラニン」色素ノ娍少．消失ハ必ズモ 蚠血/程度卜關係フルモノ＝非ス。一般全身障

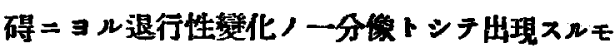
ノナラント思惟ス。

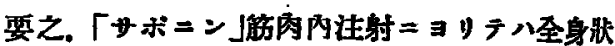

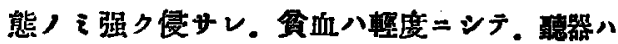
機能的ニモ器翼的ニモ㱠ンド㜔碍ナキモノ多 ク. 骨及ビ其他ノ䡱度ナル退行性䇣化八全身㷊

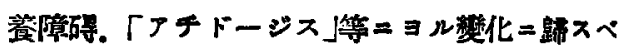
キモノナラン。

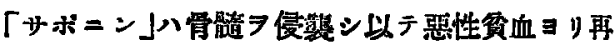
生不能性貧血习招來スべキ蓕物トサル、モ。余

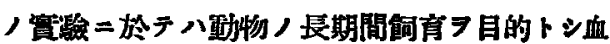
管內注射シナサズシテ筇肉内注射フナセルが 故 =「サボニン」八局所ノ細胞卜結合スル事多 ク、從ッテ骨䯣ニ至りテ之マ㻏シ以ッテ高度， 䔬血习來タスニ八至ラザリシモノナリ。

\section{第五金}

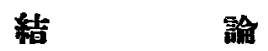

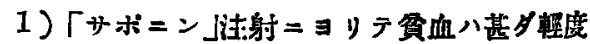
二發來スルノミナルモ。. 全身卯態八高度=淂碍

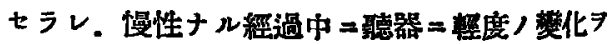
乘々ス。

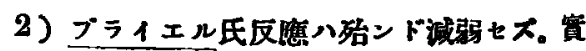

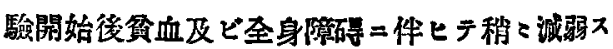

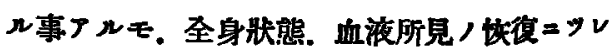

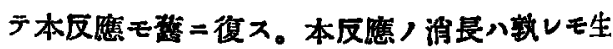
理的動摇笧圍内 = フ 。

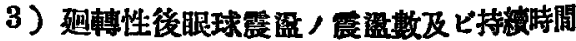
ノ整度ノ娍少及ビ短縮ヨ見ル事フリ。 


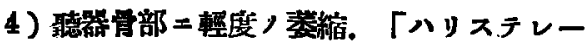
ゼ」ナリ。骨嘴中ニ「エオジン」咴好細胞ノ娍 少》認山。

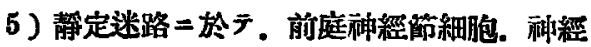

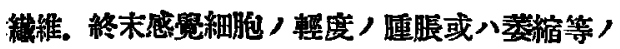
退行性變化 フ見ル事フリ。

6) 螖牛㲄迷路二於テ. 蟔旋桐經節細胞, 輕

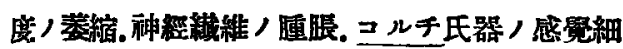

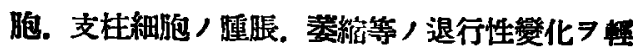
度二見ル拜厂リ。

7) 内淋巴腔上皮下及ビ脈絡帶ノ「メラニン」 色素八減少或八消失ス。

8) 上迅ノ聽器ノ諸變化八資血 非ズシテ.一般㮡荃障碍.「テチドージス」及ビ

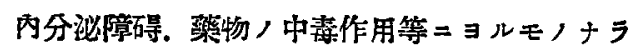
ע。 
第 1 表「サボニン」查典

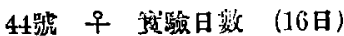

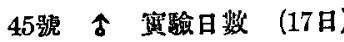

46 號 合 拱验日数 (15日)

\begin{tabular}{|c|c|c|c|c|c|c|c|c|c|c|c|c|c|c|c|c|c|c|c|c|}
\hline \multicolumn{2}{|c|}{ 日 } & $2 / 12$ & $3-8$ & 9 & \begin{tabular}{|c|}
$10-$ \\
15
\end{tabular} \mid & 16 & 17 & $18 / 12$ & $2 / 22$ & $3-8$ & \begin{tabular}{l|l}
9 & 10 \\
\end{tabular} & \begin{tabular}{c|c|}
$0-$ & 16 \\
15 & 16 \\
\end{tabular} & $\left|\begin{array}{r|}17- \\
18\end{array}\right|$ & $197 / 12$ & $\mid 2 / 12$ & $\mid 3-8$ & \begin{tabular}{l|l}
9 \\
\end{tabular} & $10-$ & 16 & $17 / 12$ \\
\hline \multicolumn{2}{|c|}{ 金身狀熊 } & 活碾 & & 元篎胞| & & 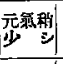 & & & 活晸 & & |活鿟 & 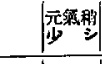 & & & $\mid$ 活磼 & & |活被 & & 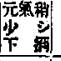 & \\
\hline \multirow[t]{2}{*}{ 骨脰 } & 重 & 415 & & 390 & & 360 & & & 350 & & $|345|$ & 315 & & & 310 & & 290 & & 260 & \\
\hline & 左 & + & & + & & + & & & + & & + & + & & & + & & + & & + & \\
\hline 拍三 & 右 & + & & + & & + & & & + & & + & +1 & & & + & & $1+$ & & + & \\
\hline \multirow{2}{*}{ 笛繁 } & 左 & 45 & & 45 & & 30 & & & 20 & & 25 & 20 & & & 25 & & 20 & & 30 & \\
\hline & |右 & 35 & & 35 & & 35 & & & 20 & & 20 & 20 & & & 35 & & 25 & & 20 & \\
\hline \multirow{2}{*}{ 眼 } & 左 & $63 / 150$ & & $|34 / 8 \cdot 0|$ & & $19 / 6 \cdot 3$ & & & $22 / 4 \cdot 6$ & & $26 / 6 \cdot 8$ & $28 / 5.8$ & & & $56 / 11 \cdot 0$ & & $41 / 60^{\circ}$ & & $53 / 8 \cdot 6$ & \\
\hline & $\mid \begin{array}{l}\text { 右 } \\
\text { 侕 }\end{array}$ & $49 / 9 \cdot 0$ & & $26 / 5 \cdot 6$ & & $3+1 / 5 \cdot 4$ & & & $22 / 4 \cdot 6$ & & $35 \%$ & $36 / 6.0$ & & & $|49 / 6 \cdot 2|$ & & $98 / 6 \cdot 0$ & & $62 / 8.4$ & \\
\hline 注 射 & 纣量 & 0.4 & 2.4 & 0.5 & $3.6 \mid 0$ & 0.7 & 0.7 & & $\left.0.35\right|^{2}$ & & 0.453. & $.0|0.6|$ & 1.2 & & \begin{tabular}{ll|l}
0.3 & 1 \\
\end{tabular} & 1.80 & 0.43 & 3.010 & 0.6 & \\
\hline \multirow{4}{*}{ 浾 } & 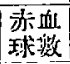 & 489 & & 434 & & 386 & & & 508 & & 497 & 424 & & & 512 & & 474 & & 327 & \\
\hline & 欰急 & 73 & & 62 & & 68 & & & 81 & & 60 & 59 & & & 70 & & 65 & & 50 & \\
\hline & $\begin{array}{l}\text { 色素指数 } \\
\end{array}$ & 0.89 & & $|0.86|$ & & 1.06 & & & $|0.96|$ & & $0.73 \mid$ & 0.83 & & & 0.82 & & 0.82 & & 0.92 & \\
\hline & 多染 & + & & + & & + & & & - & & - & $H$ & & & + & & \pm & & + & \\
\hline 血 & 監斑 & - & & - & & - & & & $1-$ & & - & - & & & - & & - & & - & \\
\hline \multirow[t]{3}{*}{ 球 } & 畸形 & - & & + & & - & & & - & & - & - & & & - & & - & & - & \\
\hline & 不同 & \pm & & + & & + & & & - & & - & $H$ & & & + & & - & & - & \\
\hline & 有赤 & -1 & & - & & - & & & - & & - & - & & & - & & - & & - & \\
\hline \multirow{3}{*}{ 白 } & 泉血留 & 12203 & & 12600 & & 9800 & & & 7800 & & 23600 & 17400 & & & 6200 & & 18000 & & 12800 & \\
\hline & 型嘴 & 0 & & 0 & & 0 & & & 0 & & 0 & 0 & & & 0 & & 0 & & 0 & \\
\hline & 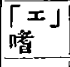 & 16 & & 11 & & 0 & & & 7 & & 6 & 0 & & & 3 & & 3 & & 0 & \\
\hline \multirow[t]{2}{*}{ 血 } & 小堛 & 31 & & 50 & & 59 & & & 37 & & 53 & 68 & & & 24 & & 70 & & 69 & \\
\hline & \begin{tabular}{|l|} 
淋巴求巴 \\
\end{tabular} & 48 & & 31 & & 31 & & & 50 & & 27 & 20 & & & 72 & & 18 & & 21 & \\
\hline \multirow[t]{2}{*}{ 球 } & \begin{tabular}{|l|} 
大單 \\
核
\end{tabular} & 5 & & 8 & & 7 & & & 6 & & 14 & 12 & & & 1 & & 9 & & 10 & \\
\hline & 核椎 & 3 & & 5 & & 3 & & & 4 & & 6 & 5 & & & 2 & & 1 & & 2 & \\
\hline \multicolumn{2}{|r|}{ 考 } & & & & & & & 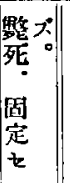 & & & & & & 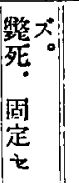 & & & & & & 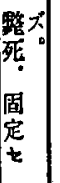 \\
\hline
\end{tabular}


第 2 表「サボニン」貿血

47 影 + 拉 羷 日 数 (28日)

\begin{tabular}{|c|c|c|c|c|c|c|c|c|c|c|c|}
\hline \multicolumn{2}{|r|}{ 日 } & $2 / 12$ & $3-8$ & 9 & $10-15$ & 16 & $17-22$ & 23 & $24-28$ & 29 & $30 / 12$ \\
\hline \multicolumn{2}{|c|}{ 全身狀匏 } & 活 波 & • & 活 澀 & & 元萗少シ & • & 宇舀少シ & & 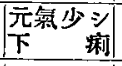 & \\
\hline \multicolumn{2}{|l|}{ 體 } & 310 & & 290 & & 280 & & 305 & & 295 & \\
\hline \multirow{2}{*}{ 拍手 } & 左 & + & . & + & & + & & + & & + & \\
\hline & 右 & + & & + & & + & & + & & + & \\
\hline \multirow{2}{*}{ 笛 㲔 } & 左 & 35 & & 35 & & 30 & & 30 & & 40 & \\
\hline & 右 & 30 & & 40 & & 25 & & 25 & & 30 & \\
\hline \multirow{2}{*}{ 眼 篇 } & 左迴 & $49 / 5 \cdot 8$ & & $20 / 4 \cdot 2$ & & $26 / 5 \cdot 4$ & & $25 / 5.0$ & & $22 / 4 \cdot 8$ & \\
\hline & 右超 $\mid$ & $46 / 5 \cdot 4$ & & $2 \pi / 54$ & & $27 / 5 \cdot 4$ & & ${ }^{27} / 4 \cdot 8$ & & $17 / 3 \cdot 6$ & \\
\hline & 射 量 & 0.3 & 1.8 & 0.4 & 3.0 & 0.5 & 2.4 & 0.2 & 1.0 & 0.3 & \\
\hline \multicolumn{2}{|r|}{ 赤血球數 } & 499 & & 403 & & 456 & & 465 & & 463 & \\
\hline \multirow{2}{*}{ 赤 } & 血色素量 & 78 & & 62 & & 60 & & 61 & & 74 & \\
\hline & 色系指好 & 0.94 & & 0.92 & & 0.79 & & 0.79 & & 0.96 & \\
\hline \multirow{2}{*}{ 血 } & 多染 抄 & - & & + & & + & - & + & & + & \\
\hline & 玟 & - & & - & & - & & - & & - & \\
\hline \multirow{3}{*}{ 球 } & 畸形 & - & & - & & - & & + & & - & \\
\hline & 不 同 & - & & + & & - & & + & & - & \\
\hline & 有 赤 & - & & - & & - & & - & & - & \\
\hline \multirow{3}{*}{ 白 } & 白血球数 & 6000 & & 10400 & & 10400 & & 12600 & & 10000 & \\
\hline & 嚂赌 & 0 & & 0 & & 0 & & 0 & & 1 & \\
\hline & $\lceil 土 」$ 嗜 & 3 & & 4 & & 5 & & 0 & & 0 & \\
\hline \multirow[t]{2}{*}{ 血 } & 中，嗜 & 18 & & 52 & & 64 & & 65 & & 51 & \\
\hline & 淋巴球 & 74 & & 36 & & 17 & & 30 & & 40 & \\
\hline \multirow[t]{2}{*}{ 球 } & 大單核 & 5 & & 8 & & 14 & & 5 & & 8 & \\
\hline & $\mid$ 核 椎 & 0 & & 4 & & 2 & & 5 & & 4 & \\
\hline & 考 & & & & & & & & & & 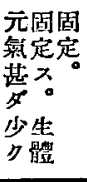 \\
\hline
\end{tabular}


第 3 表「サボ二ン」餐血

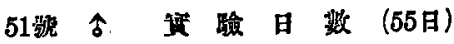

\begin{tabular}{|c|c|c|c|c|c|c|c|c|c|c|c|c|c|c|c|c|}
\hline \multicolumn{2}{|r|}{ H } & $\mid 18 / 12$ & \begin{tabular}{|c|c|}
$19-22$ & 23 \\
\end{tabular} & & $\left.29\right|^{3}$ & \begin{tabular}{|l|l|}
$31-5 / 1$ & 6 \\
4
\end{tabular} & \begin{tabular}{|l|l|}
$8-12$ & 13 \\
\end{tabular} & \begin{tabular}{|c|}
$15-$ \\
17 \\
\end{tabular} & \multicolumn{2}{|c|}{ 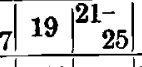 } & \multicolumn{3}{|c|}{$6\left|\begin{array}{c|c}28- & 1 / 2 \\
30\end{array}\right|$} & \multirow{2}{*}{$\frac{|3-7|}{\mid}$} & \multirow{2}{*}{\begin{tabular}{|c|}
8 \\
7
\end{tabular}} & \multirow{2}{*}{ 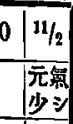 } \\
\hline 조 & 身 状 留 & 活磁 & $\mid \begin{array}{l}\text { 就骕 } \\
\text { 少 }\end{array}$ & & 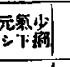 & 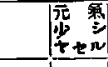 & 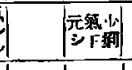 & & 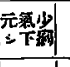 & & $\mid$ & & 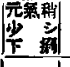 & & & \\
\hline 顝 & 重 & 430 & 400 & & 400 & 375 & 380 & & 390 & & 370 & & 360 & & 415 & \\
\hline \multirow{2}{*}{ 拍 } & t t & + & + & & + & \pm & + & & + & & + & & + & & + & \\
\hline & 右 & + & + & & + & + & + & & + & & + & & + & & + & \\
\hline \multirow{2}{*}{ 笛 } & 左 & 35 & 35 & & 30 & 40 & 40 & & 35 & & 25 & & 35 & & 35 & \\
\hline & 右 & 30 & 30 & & 20 & 30 & 30 & & 30 & & 20 & & 30 & & 30 & \\
\hline \multirow{2}{*}{ 眼 } & 左趈 & $23 / 4 \cdot 6$ & $\mid 21 / 4 \cdot 4$ & & $20 / 4 \cdot 2$ & $15 / 3 \cdot 6$ & {$[18 / 4 \cdot 6$} & & $18 / 4 \cdot 2$ & & $|10 / 4 \cdot 6|$ & & $12 / 3 \cdot 6$ & & $15 / 2 \cdot 8$ & \\
\hline & 右趈 & $2 \pi / 48$ & $23 / 4 \cdot 6$ & & $24 / 9 \cdot 6$ & $\mid i 4 / 4 \cdot 4$ & $|23 / 5-4|$ & & $22 / 48$ & & $20 / 4 \cdot 8$ & & $14 / 4-4$ & & $15 / 3.8$ & \\
\hline \multicolumn{2}{|c|}{ 注 . 射 } & 0.5 & \begin{tabular}{|l|l|}
0.8 & 0.2 \\
\end{tabular} & 1.0 & 0.3 & $0.9|0.4|$ & $\left|\begin{array}{lll}1.2 & 0.4\end{array}\right|$ & 0.8 & 0.5 & 1.5 & 0.5 & 1.0 & 0.5 & 1.5 & 0.6 & \begin{tabular}{l|l|}
0.6 & 0.6 \\
\end{tabular} \\
\hline \multicolumn{2}{|r|}{ 赤血球擞 } & 501 & 306 & & 406 & 451 & 493 & & 451 & & 512 & & 474 & & 501 & \\
\hline \multirow[b]{2}{*}{ 赤 } & 血色素量 & 92 & 62 & & 67 & 80 & 75 & & 91 & & 83 & & 78 & & 82 & \\
\hline & 色素指数 & 1.10 & 1.22 & & 0.99 & 1.06 & $|0.91|$ & & 1.21 & & 0.97 & & 0.99 & & 0.98 & \\
\hline \multirow{2}{*}{ 血 } & 多染性 & + & +1 & & + & \pm 1 & + & & + & & + & & + & & + & \\
\hline & 䤈 斑 & - & - & & - & -1 & - & & - & & - & & - & & + & \\
\hline \multirow{3}{*}{ 球 } & 渏 形 & - & -1 & & - & - & - & & - & & - & & - & & - & \\
\hline & 不同 & -1 & +1 & & + & + & + & & + & & + & & - & & - & \\
\hline & 有 赫 & - & - & & - & -1 & - & & - & & - & & - & & - & \\
\hline \multirow{3}{*}{ 白 } & 白血球数 & 12000 & 8000 & & 12800 & 7200 & 8800 & & $16000 \mid$ & & 17800 & & 28400 & & 14200 & \\
\hline & 潇 & 0 & 0 & & 0 & 0 & 0 & & 0 & & 0 & & 0 & & 0 & \\
\hline & 「土」啫 & 3 & 0 & & 0 & 0 & o & & 0 & & 2 & & 1 & & 0 & \\
\hline \multirow[t]{2}{*}{ 血 } & 中 鈚 & 33 & 42 & & 65 & 59 & 59 & & 76 & & 46 & & 64 & & 74 & \\
\hline & 淋巴球 & 55 & 50 & & 30 & 31 & 28 & & 22 & & 39 & & 27 & & 19 & \\
\hline \multirow[t]{2}{*}{ 球 } & 大單校 & 9 & 8 & & 5 & 10 & 13 & & 2 & & 13 & & 8 & & 7 & \\
\hline & 核 椎 & 1 & 5 & & 2 & 1 & 3 & & 4 & & 4 & & 4 & & 5 & \\
\hline & 備 & & & & & & 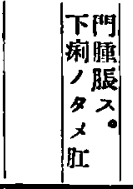 & & & & & $\begin{array}{l}\text { 注 } \\
\text { 射 } \\
\text { 部 } \\
\text { 位 } \\
\text { 化 } \\
\text { 踐 }\end{array}$ & & & & 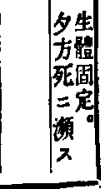 \\
\hline
\end{tabular}


第 4 表「サボニン」賈血

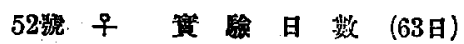

\begin{tabular}{|c|c|c|c|c|c|c|c|c|c|c|c|c|c|c|c|c|c|c|c|c|}
\hline \multirow{2}{*}{\multicolumn{2}{|c|}{ 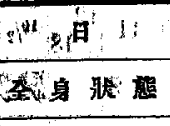 }} & $128 / 12$ & \begin{tabular}{|r|}
$19-$ \\
25
\end{tabular} & 26 & $\begin{array}{r}27- \\
30\end{array}$ & $31 \mid$ & $1 / 1-5$ & \begin{tabular}{l|l|l|}
$6 / 1$ & 7 \\
\end{tabular} & $7-12$ & 13 & $\begin{array}{c}14- \\
18\end{array}$ & 19 & \begin{tabular}{|c|}
$20-$ \\
24
\end{tabular} & $\left.25\right|^{2}$ & \begin{tabular}{|c|}
$20-$ \\
$3 / 2$
\end{tabular} & \begin{tabular}{|l|l|}
$4 / 2$ & 5 \\
\end{tabular} & $5-10$ & \begin{tabular}{|l|l}
11 \\
\end{tabular} & $\begin{array}{c}12- \\
18\end{array}$ & $19 / 2$ \\
\hline & & 活涨 & & 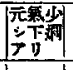 & & 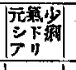 & & 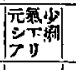 & & $\begin{array}{l}\text { 元氮 } \\
\text { 少シ }\end{array}$ & & 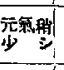 & & 活知 & & 㣊舆 & & 活灣 & & 元雬犁 \\
\hline \multicolumn{2}{|r|}{ 重 } & 370 & & 330 & & 340 & & 330 & & 340 & & 370 & & $360 \mid$ & & 390 & & 370 & & 370 \\
\hline \multirow{2}{*}{$+{ }_{+}^{+}$手 } & 苪 & + & . & + & & + & & + & & + & & + & & + & & + & & + & & + \\
\hline & 右 & + & & + & & + & & + & & + & & + & & + & & + & & + & & + \\
\hline \multirow{2}{*}{ 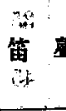 } & 左 & 30 & & 20 & & 20 & & 35 & & 25 & & 30 & & 20 & & 35 & & 35 & & 30 \\
\hline & 右 & 25 & $\because$ & 20 & & 20 & & 30 & & 30 & & 25 & & 20 & & 35 & & 30 & & 30 \\
\hline \multirow{2}{*}{ 眼 } & 左䞝 & $45 / 8 * 8$ & & $46 / 8.8$ & & $40 / 8 \cdot 2$ & & $49 / 9 \cdot 2$ & & $43 / 8 \cdot 4$ & & $96 / 6 \cdot 8$ & & $35 / 6 \cdot 6$ & & $2 x / 6=2$ & & $30 / 6.2$ & & $20 / 5 \cdot 2$ \\
\hline & \begin{tabular}{l|l} 
右䞤 \\
\end{tabular} & $48 / 8 \cdot 0$ & & $20 / 6=4$ & & $28 / 6 \cdot 2$ & & $27 / 6 \cdot 8$ & & $21 / 6 \cdot 0$ & & $20 / 5 \cdot 0$ & & $12 / 4 \cdot 2$ & & $|14 / 4 \cdot 4|$ & & $\mid 18 / 4 \cdot 8$ & & $167 / 4 \cdot 3$ \\
\hline 注 & 射 豆 & 0.5 & $\mid 1.4$ & 0.2 & 0.6 & 0.3 & 0.6 & 0.3 & 0.9 & 0.3 & 0.6 & 0.4 & 1.2 & 0.3 & $|1.6|$ & 0.5 & 1.5 & 0.6 & 2.4 & \\
\hline \multirow[t]{2}{*}{4} & 赤血球制 & 460 & & 453 & & $|421|$ & & 371 & & 417 & & 415 & & 432 & & 388 & & 428 & & 523 \\
\hline & 血色素量 & 76 & & 72 & & 76 & & 62 & & 65. & & 70 & & 73 & & 62 & & 73 & & 78 \\
\hline 赤 & 色素指数 & 0.99 & & $|0.95|$ & & 1.08 & & 1.00 & & 0.94 & & 1.01 & & 1.01 & & 0.96 & & $\mid 1.02$ & & 0.89 \\
\hline \multirow{2}{*}{ 血 } & 多染性 & +1 & & + & & + & & + & & + & & + & & + & & + & & + & & + \\
\hline & 盖 斑 & -1 & & + & & - & & - & & + & & - & & - & & - & & - & & - \\
\hline \multirow{2}{*}{ 球 } & 躸 形 & - & & + & & + & & + & & - & & - & & - & & + & & - & & - \\
\hline & 不同 & -1 & & + & & $1+$ & & + & & + & & - & & \pm & & + & & \pm & & - \\
\hline & 有 赤 & -1 & & - & & - & & - & & +1 & & - & & - & & - & & - & & - \\
\hline \multirow{3}{*}{ 柏 } & 自血球數 & 13000 & & 14400 & & 11800 & & 10400 & & 12400 & & 17200 & & 26200 & & 27000 & & 42600 & & 31800 \\
\hline & 䯠啫 & 0 & & 0 & & 1 & & 1 & & 0 & & 1 & & 0 & & 0 & & 0 & & 0 \\
\hline & 「土」啫 & 0 & & 0 & & 0 & & 0 & & 2 & & 1 & & 2 & & 0 & & 1 & & 0 \\
\hline 孟 & 中：嗜 & 40 & & 61 & & 50 & & 60 & & 66 & & 59 & & 48 & & 49 & & 53 & & 60 \\
\hline \multirow{3}{*}{ 球 } & 淋巴球 & 45 & & 34 & & 45 & & 32 & & 22 & & 35 & & 45 & & 48 & & 42 & & 32 \\
\hline & 大單核 & 15 & & 5 & & 4 & & 7 & & 10 & & 4 & & 5 & & 3 & & 4 & & 8 \\
\hline & 核，雄 & 3 & & 6 & & 4 & & 4 & & 4 & & 2 & & 4 & & 6 & & 3 & & 0 \\
\hline 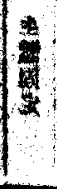 & 考 & & & & & & & & & & & & & & 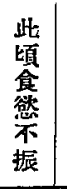 & & & & & \begin{tabular}{|l} 
告 \\
體 \\
定 \\
定
\end{tabular} \\
\hline
\end{tabular}


第 5 表 「サボニン」質血

53號古算羷 日 票 (63日)

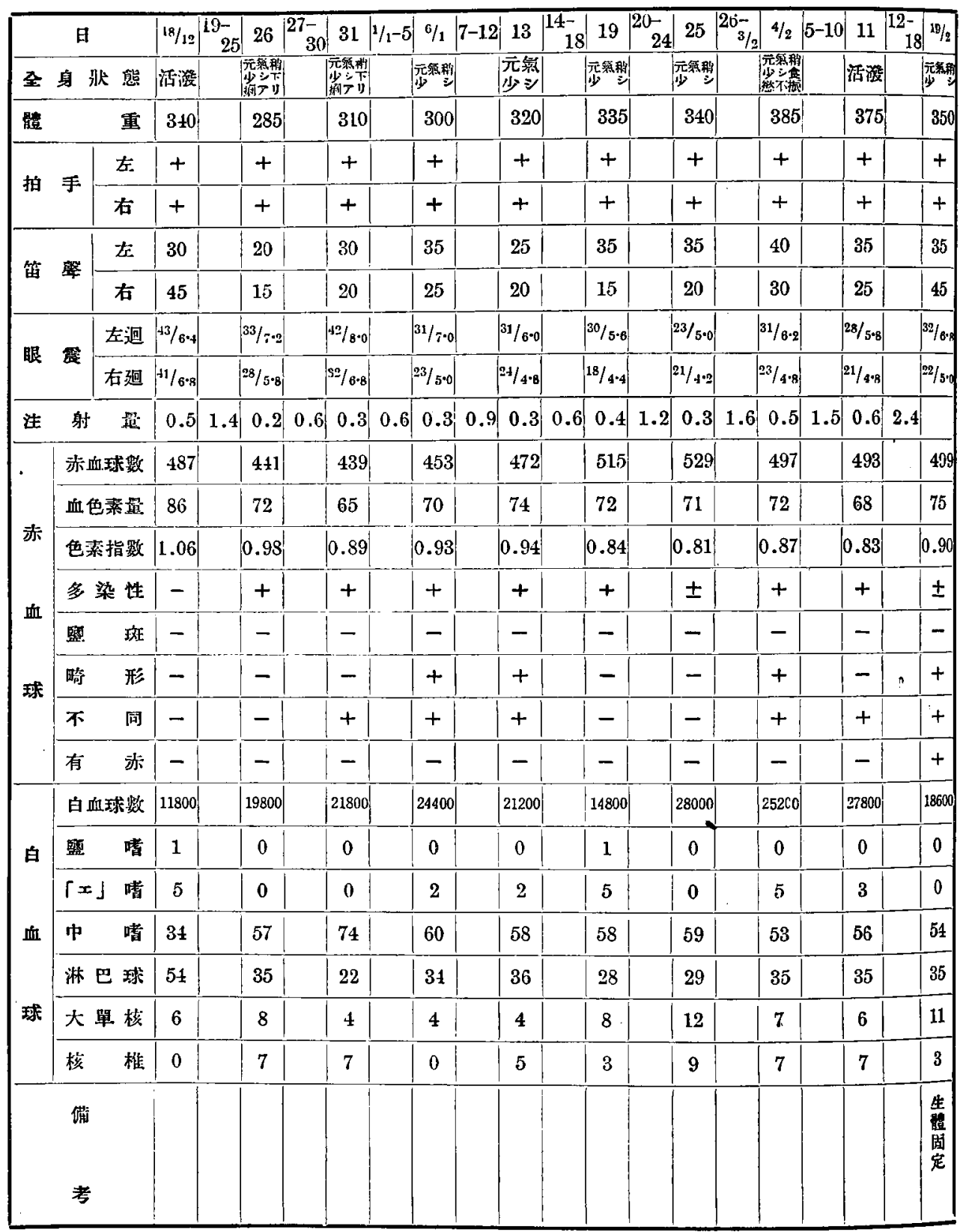


第 5 表附圆「「サポニン」幊血

第 53 磻 (63日)

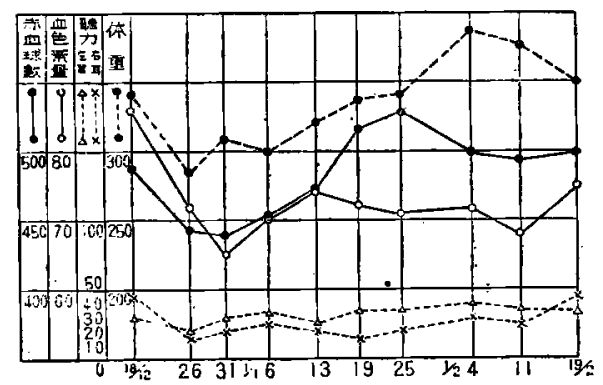

